\title{
ANALISIS DAN PERANCANGAN SISTEM PERSONALISASI DAN MONITORING SLA (SERVICE LEVEL AGREEMENT) BERBASISKAN NFC (NEAR FIELD COMMUNICATION) STUDI KASUS AKSES KONTROL VENDOR KE PERANGKAT BTS (BASE TRANSCEIVER STATION)
}

\author{
NOFITA RISMAWATI \\ Program Studi Informatika \\ Universitas Indraprasta PGRI, Jakarta, Indonesia \\ Jl. Nangka No. 58 C Tanjung Barat, Jagakarsa, Jakarta 12530 \\ MUHAMAD FEMY MULYA \\ Program Studi Sistem Informasi \\ Tanri Abeng University, Jakarta, Indonesia \\ Jl. Swadarma Raya No.58, Ulujami, Pesanggrahan, Jakarta 12250 \\ Email: novi.9001@gmail.com, femy.mulya@ tau.ac.id
}

\begin{abstract}
Abstrak. NFC (Near Field Communication) adalah salah satu teknologi komunikasi antar gadget terbaru yang menggunakan sistem RFID (Radio Frequency Identification) untuk saling bertukar data dalam jarak dekat, sekitar 4 inci. Teknologi NFC (Near Field Communication) merupakan prinsip komunikasi nirkabel standar yang memungkinkan dua perangkat untuk bertukar data saat dalam posisi berdekatan satu sama lain. Tujuan dari penelitian ini adalah untuk menganalisa dan merancang suatu sistem personalisasi untuk vendor dengan memanfaatkan teknologi NFC (Near Field Communication) yang dapat mempermudah vendor untuk mengakses ke pintu perangkat BTS (Base Tranceiver Station) dan sekaligus membantu operator telekomunikasi dalam memonitoring SLA (Service Level Agreement) untuk setiap vendor-vendor yang melakukan troubleshooting langsung ke perangkat BTS (Base Tranceiver Station), sehingga performa vendor dapat termonitor. Selain itu juga, membantu pihak yang berkepentingan (dalam hal ini, pihak manajemen operator telekomunikasi) dalam penilaian kinerja suatu vendor. Penelitian ini menggunakan metode penelitian model Prototype/Prototyping dengan pendekatan Unified Modelling Language (UML) dan Analisis PIECES (Performance, Information, Economy, Eficiency, Services). Hasil dari penelitian ini adalah sebuah rancangan prototype sistem personalisasi untuk vendor berbasiskan teknologi NFC (Near Field Communication), serta hasil uji coba akurasi pembacaan prototype dari sistem personalisasi NFC (Near Field Communication) dengan NFC Reader.
\end{abstract}

Kata Kunci: NFC, BTS, SLA

Abstract. NFC (Near Field Communication) is one of the communication technologies between the latest gadgets that use RFID (Radio Frequency Identification) systems to exchange data at close range, about 4 inches. NFC (Near Field Communication) technology is the principle of standard wireless communication that allows two devices to exchange data when in a position close to one another. The purpose of this research is to analyze and design a personalization system for vendors by utilizing NFC (Near Field Communication) technology that can facilitate vendors to access the doors of BTS (Base Tranceiver Station) devices and at the same time help telecommunications operators in monitoring SLAs (Service Level Agreement) for every vendor who does troubleshooting directly to a BTS (Base Tranceiver Station) device, so that vendor performance can be monitored. In addition, it also helps interested parties (in this case, the telecommunications operator management) in evaluating the performance of a vendor. This 
study uses the Prototype/Prototyping model research method with the Unified Modeling Language (UML) approach and PIECES Analysis (Performance, Information, Economy, Efficiency, Services). The results of this study are a personalization prototype system design for vendors based on NFC (Near Field Communication) technology, as well as the results of testing the accuracy of prototype readings from the NFC (Near Field Communication) personalization system with NFC Reader.

Key words: NFC, BTS, SLA

\section{PENDAHULUAN}

Dewasa ini perkembangan perangkat teknologi komunikasi berkembang dengan sangat cepat. Berbagai upaya dilakukan untuk mempermudah pekerjaan manusia dari waktu kewaktu dengan tingkat mobilitas tinggi dalam melakukan pekerjaannya serta otomatisasi sehingga manusia mendapat kemudahan dari perkembangan teknologi saat ini.

Penggunaan teknologi mobile sekarang ini menjadi bagian dari gaya hidup bagi sebagian orang. Sebagai contohnya adalah semakin tingginya angka pengguna smartphone di seluruh dunia dan begitu juga di Indonesia, dengan adanya smartphone inilah kini setiap orang dapat mudah dan cepat dalam mengakses berbagai macam informasi. Seperti informasi yang dilansir dari www.statista.com, pemakai smartphone Indonesia diprediksi akan mencapai angka 103 juta pengguna pada tahun 2017 (Statista, 2011).

Dengan adanya kebutuhan akan kecepatan proses transaksi dan kemudahan dalam memperoleh informasi, maka pada penelitian ini akan dibahas mengenai pemanfaatan perangkat teknologi NFC (Near Field Communication) pada transaksi yang dilakukan, dengan mengoptimalkan teknologi NFC yang ada di dalam telepon genggam dan NFC yang tertanam di kartu (Rismawati, Nofita. 2016).

PT. XL Axiata, Tbk, PT. Telkomsel, Tbk, PT. Indosat Oredo, Tbk adalah beberapa operator seluler di Indonesia yang bergerak di bidang telekomunikasi. Untuk menjalankan core business perusahaan, setiap operator telekomunikasi banyak bekerja sama dengan berbagai macam vendor-vendor telekomunikasi, seperti Ericsson, Huawei, Alcatel, IBM, Nokia Siemens, Cisco, Juniper dan masih banyak lagi vendor yang lainnya. Vendor-vendor tersebut berperan sebagai penyedia perangkat jaringan sekaligus sebagai service dan support jaringan.

Pada pengimplementasiannya perangkat-perangkat jaringan tersebut mungkin saja terdapat masalah, oleh sebab itu setiap operator telekomunikasi memiliki mekanisme masing-masing untuk menangani laporan masalah (trouble report), baik pelaporan jika terjadi masalah atau jika suatu masalah telah diperbaiki. Mekanisme tersebut adalah jika suatu masalah terjadi pada perangkat jaringan, maka karyawan yang menemukan masalah tersebut harus menghubungi NOC-Network Coordinator untuk kemudian laporan tersebut diteruskan ke vendor yang bersangkutan. Pada proses eskalasi untuk troubleshooting di lapangan, pihak NOC-Network Coordinator akan memberikan akses personalisasi kepada vendor bersangkutan agar bisa mengakses pintu perangkat BTS (Base Tranceiver Station).

Dengan memanfaatkan teknologi NFC (Near Field Communication) diharapkan setiap vendor memiliki akses ke pintu perangkatnya masing-masing tanpa mengganggu perangkat vendor lainnya, serta dapat dijadikan parameter untuk perhitungan SLA (Service Level Agreement) untuk proses eskalasi dari masing-masing vendor. Dan apabila masalah telah teratasi, vendor memberi laporannya kepada NOC-Network Coordinator untuk kemudian akan dikembalikan kepada karyawan yang melaporkan permasalahan tersebut untuk dipastikan apakah masalah tersebut sudah diatasi dengan baik. Jika semua masalah sudah terselesaikan, maka NOC-Network Coordinator bisa menutup (closed) laporan masalah (trouble report) terkait problem yang telah di troubleshooting. Terkait dengan semua laporan masalah (trouble report), pihak manajemen dapat memproses perhitungan SLA (Service Level Agreement) achievement 
yang didapat dari masing-masing vendor untuk dijadikan tolak ukur performance dan service quality setiap vendor.

Penelitian ini penting dilakukan, karena pada penelitian-penelitian yang sudah dilakukan masih menggunakan teknologi RFID (Radio Frequency IDentification) dan belum ada yang memanfaatkan teknologi NFC (Near Field Communication) untuk akses ke pintu BTS (Base Tranceiver Station), serta tidak adanya parameter uji coba pembacaan sistem personalisasi NFC Tag dengan NFC Reader dalam bentuk persentase.

Dari uraian yang telah diberikan, pada penelitian ini akan dijawab permasalahan otomasi sistem personalisasi dan monitoring akses kontrol vendor ke perangkat BTS (Base Transceiver Station) dengan mengembangkan suatu perangkat lunak personalisasi dan pengelola data vendor yang berbasiskan teknologi NFC (Near Field Communication). Perangkat lunak ini diharapkan dapat dimanfaatkan oleh pihak manajemen operator telekomunikasi dalam mengambil keputusan berkaitan dengan performa vendor. Perangkat lunak yang akan dikembangkan menggunakan JSP (Java Servlet Page).

\section{Near Field Communication (NFC)}

Near Field Communication (NFC) merupakan teknologi komunikasi data terbaru yang memakai induksi magnet berbasis teknologi Radio Frequency Identification (RFID). NFC sudah dikembangkan pada tahun 2002 oleh NXP dan Sony. (Rismawati, Nofita. 2016).

NFC akan saling terkoneksi ketika 2 perangkat yang mendukung NFC bertemu dan salah satunya menjadi inisiator atau sebagai target. Perangkat NFC diantaranya adalah smartphone, kartu (tag) NFC dan NFC Reader. Jenis koneksi NFC dibagi menjadi 3 yaitu (Lee, H. 2014):

1. NFC pada ponsel $\rightarrow$ Kartu NFC (NFC Tag),

2. NFC pada ponsel $\rightarrow$ NFC Reader,

3. NFC pada ponsel $\rightarrow$ NFC pada ponsel.

Berdasarkan jenis koneksi di atas, teknologi NFC menawarkan 3 mode operasi: card emulation, read/write dan peer-to-peer.

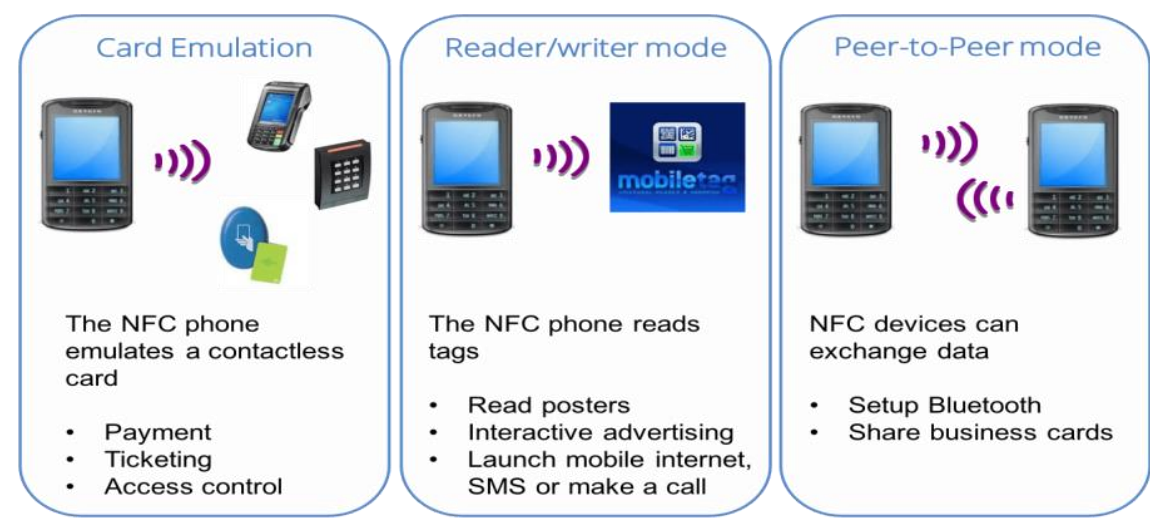

Gambar 1. Mode Operasi Pada NFC (Near Field Communication)

\section{Cara Kerja Near Field Communication (NFC)}

Cara kerja NFC sendiri sama seperti dengan Bluetooth \& WiFi, yaitu melakukan koneksi Wireless berbasis radio frekuensi. Perbedaannya sebagai berikut:

1. Koneksi Bluetooth/WiFi menggunakan konfigurasi teknis tertentu, sedangkan NFC untuk dapat berkomunikasi hanya perlu mendekatkan atau Tap Smartphone dengan terminal NFC. 
2. Bluetooth \& WiFi menggunakan frekuensi $2.4-2.5 \mathrm{GHz}$, sedangkah NFC menggunakan frekuensi rendah $13.56 \mathrm{MHz}$.

3. Jarak komunikasi transfer Bluetooth kurang lebih 3 meter, sedangkan jarak komunikasi $W i F i$ kurang lebih 100 meter, sedangkan jarak komunikasi NFC tidak lebih dari $10 \mathrm{~cm}$.

4. NFC hanya mentransfer data berkapasitas rendah (satuan kilobyte), karena hanya untuk melakukan otorisasi, informasi kecil, transaksi \& pembayaran.

5. Waktu setup atau konfigurasi koneksi NFC hanya $<0,1$ detik (kurang dari 0,1 detik), sedangkan Bluetooth/WiFi bisa lebih dari 6 detik.

NFC membutuhkan dua perangkat untuk saling berkomunikasi, yang biasa dinamakan NFC Reader dan NFC Tags. NFC Reader adalah Smartphone/Ponsel pengguna yang sudah tertanam fitur NFC. NFC Tags sendiri adalah terminal kecil yang didalamnya terdapat sebuah Chip (IC) NFC dan memiliki antena radio terintegrasi. NFC Tags mampu menyimpan berbagai informasi yang sudah ditentukan oleh penggunanya, seperti: informasi diskon atau promo, peta, harga atau tiket. Dengan demikian saat melakukan proses transaksi pembayaran, Smartphone yang sudah ada NFC Tags dan NFC Reader akan saling berdekatan, sehingga terjadi proses transaksi secara otomatis. Pada dasarnya, perangkat NFC memanfaatkan medan elektromagnetik untuk menjalankan proses transfer data. Saat Smartphone didekatkan ke Terminal NFC, NFC Reader akan mentrigger untuk mengaktifkan signal didalam NFC Tags. Sehingga kedua perangkat ini dapat langsung berkomunikasi, dimana NFC Reader mengambil informasi didalam NFC Tags, dan NFC Reader mengirimkan informasi itu ke server.

\section{Komunikasi Near Field Communication (NFC)}

Komunikasi data pada Near Field Communication (NFC) memiliki 2 mode operasi yaitu mode aktif dan mode pasif.

1. Pada mode aktif, NFC yang berperan menjadi inisiator akan mengaktifkan transmitter, sehingga aliran arus dengan frekuensi tinggi yang mengalir pada antena membentuk medan magnetik $\mathrm{H}$ yang menyebar disekitarnya, seperti terlihat pada gambar 2 dibawah. Sebagian akan bergerak dan tertangkap oleh antena interface NFC yang terletak pada lokasi yang saling berdekatan. Kemudian tegangan U dihasilkan oleh antena yang dapat mendeteksi dan menerima frekuensi oleh receiver pada NFC target.

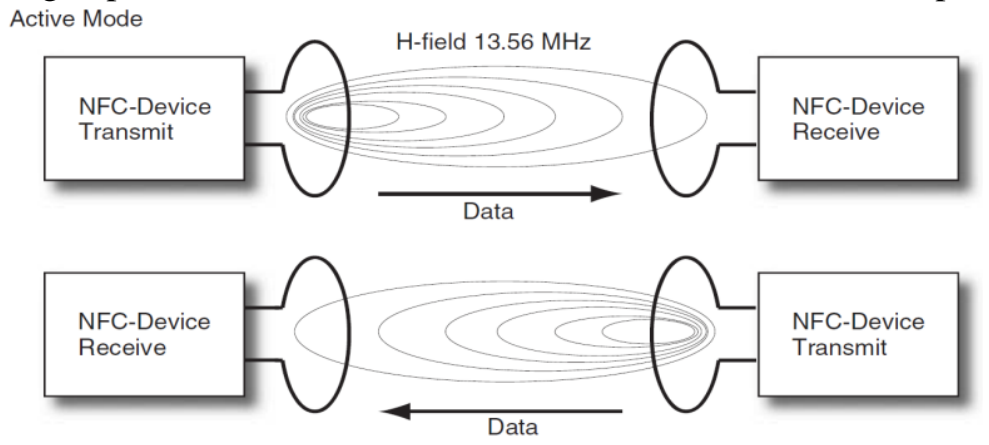

Gambar 2. Mode Aktif Pada NFC

2. Pada mode pasif, NFC inisiator menghasilkan medan magnetik untuk dapat berkomunikasi dengan NFC target. Namun setelah paket data sampai ke target tujuan, NFC inisiator tidak akan merubah mode menjadi penerima seperti NFC mode aktif, melainkan akan tetap mengaktifkan transmitter. Dengan demikian trasmitter hanya diaktifkan pada NFC inisiator. 

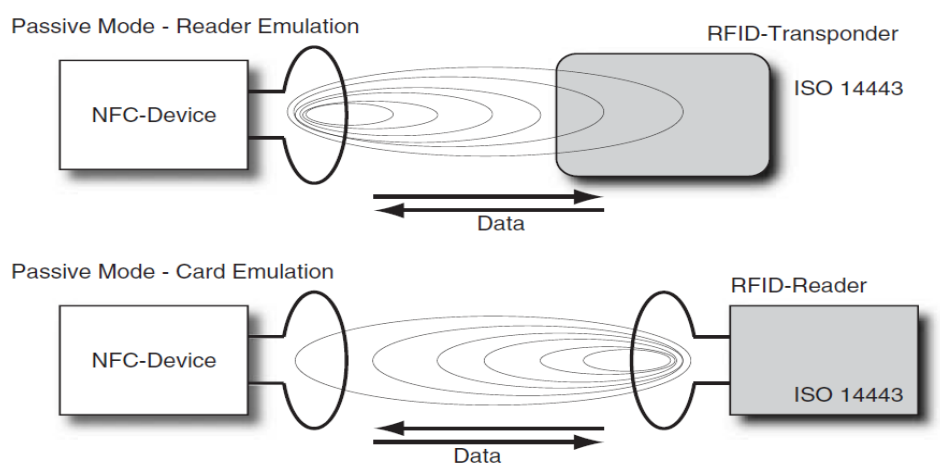

Gambar 3. Mode Pasif Pada NFC

(https://nicoruslim.wordpress.com/2014/07/20/rfid-nfc-mode-aktif-dan-pasif/, 29September 2018).

\section{BTS (Base Tranceiver Station)}

BTS merupakan kepanjangan dari Base Transceiver Station. BTS pada umumnya berfungsi untuk menjembatani perangkat komunikasi pengguna dengan jaringan menuju ke jaringan lainnya. Satu cakupan pancaran BTS biasa disebut dengan Cell. Pada dasarnya, beberapa BTS biasanya dikontrol oleh satu Base Station Controller (BSC) yang dihubungkan dengan koneksi jaringan microwave ataupun serat optik (Dynastya., \& Haryo S. 2013).

Komponen suatu BTS biasanya terdiri dari berbagai macam perangkat jaringan dan telekomunikasi. Hanya saja yang paling populer yaitu komponen tower (menara), karena memang tower lah yang paling jelas dilihat orang. Selain tower, rangkaian utama lain yakni shelter (rumah BTS), dan feeder.

Pada umumnya shelter BTS berdimensi 3 x 3 meter, dengan cat warna putih. Di dalamnya terdapat berbagai jenis perangkat penting jaringan dan telekomunikasi, diantaranya adalah module combiner, module per carrier, core module (module inti), power supply, fan (kipas) pendingin, dan AC/DC converter. Seluruh perangkat dalam shelter BTS berbentuk seperti rakrak besi, atau malah lebih mirip seperti lemari pendingin. Rak besi biasanya disebut sebagai BTS Equipment (BTSE). Sebagai sumber tenaga bagi perangkat BTS, rata-rata diperlukan range energi sebesar 25 sampai 45 watt, tergantung module dan hardware yang digunakan.

Dalam industri jaringan telekomunikasi selular, perangkat seperti BTS termasuk bagian dari BSS (Base Station Subsystem). Selain komponen BTS, dalam BSS juga dikenal istilah BSC (Base Station Controler), dimana beberapa BTS ditangani oleh satu buah BSC. selain BSS, terdapat komponen penting lain yang bernama SSS (Switching Subsystem), dalam komponen SSS biasanya mencakup kombinasi dari berbagai perangkat seperti MSC (master switching control), HLR (home location register), dan VLR (visitor location register). Singkatnya dalam topologi jaringan GSM terdapat tiga komponen penting yakni BSS, SSS, dan intelligent network. 


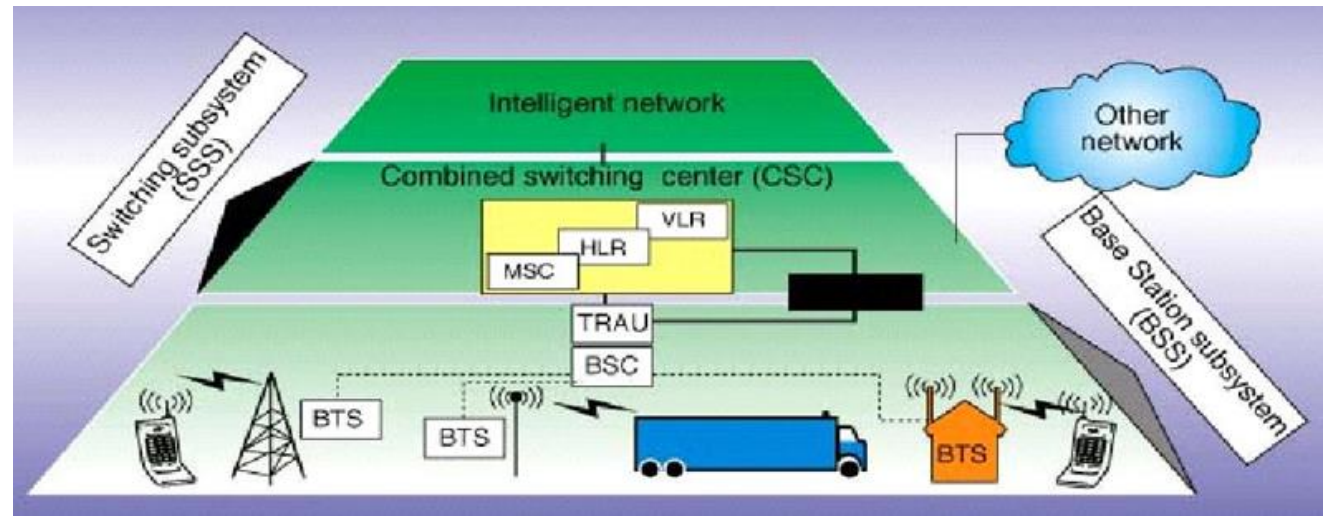

Gambar 4. Alur sistem BSS (Base Station Subsystem)

\section{METODE}

Untuk menganalisa dan merancang sistem personalisasi dan monitoring SLA (Service Level Agreement) berbasiskan NFC (Near Field Communication) yang benar dan sesuai dengan konsep yang diperoleh maka penulis menggunakan metode penelitian model Prototype/Prototyping dan Analisis PIECES. Adapun tahapan Prototype/Prototyping yang terdiri dari (A. Dayumi and M. Femy. 2018):

1. Pengumpulan Kebutuhan,

2. Membangun Prototype/Prototyping,

3. Evaluasi Prototyping,

4. Mengkodekan Sistem,

5. Menguji Sistem,

6. Evaluasi Sistem,

7. Menggunakan Sistem.

Metode PIECES digunakan untuk menganalisa kinerja informasi, ekonomi, keamanan aplikasi, efisiensi, dan pelayanan pelangganan. Analisa PIECES dibagi menjadi Performance, Information, Economy, Eficiency, Services (A. Dayumi and M. Femy. 2018).

\section{HASIL DAN PEMBAHASAN}

\section{Analisis Permasalahan}

Berikut adalah beberapa permasalahan yang diidentifikasi dan beberapa diantaranya direalisasikan dalam penelitian ini :

1. Adanya Kesulitan pihak Manajemen Operator Telekomunikasi dalam memberikan evidence kepada Vendor terkait Out of SLA Issue.

2. Bagaimana cara meminimalisir miscommunication antar vendor dan NOC operator telekomunikasi terkait SOP akses ke perangkat BTS.

3. Bagaimana membangun suatu sistem personalisasi trouble report untuk vendor dengan memanfaatkan teknologi NFC (Near Field Communication) yang dapat mempermudah akses ke pintu perangkat BTS (Base Tranceiver Station)?

4. Bagaimana membangun suatu sistem yang dapat mencatat, melaporkan dan membedakan setiap akses vendor yang akan melakukan proses troubleshoot di lapangan?

5. Bagaimana membangun suatu sistem yang dapat mempermudah proses penghitungan SLA (Service Level Agreement) achievement yang didapat dari vendor-vendor yang bekerjasama dengan Operator Telekomunikasi? 


\section{Rancangan Bisnis Proses}

Dari permasalahan yang didapat, kemudian dilakukan wawancara langsung dengan bagian NOC-Network Coordinator dan Field Operation pada operator telekomunikasi, maka didapat rancang solusi seperti gambar berikut:

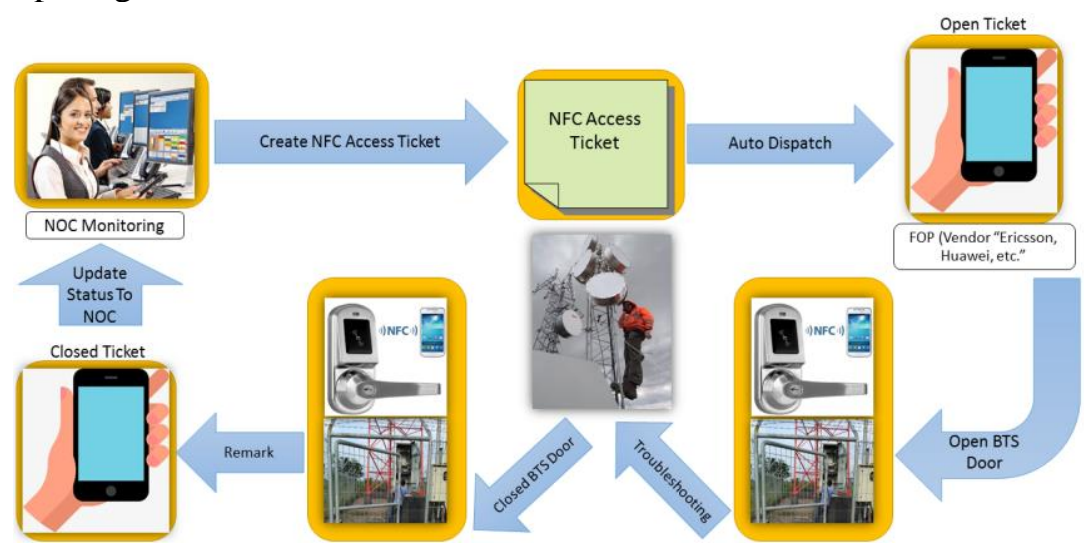

Gambar 5. Rancangan Bisnis Proses Eskalasi Trouble Ticket dengan NFC

1. Pada Sistem Monitoring BTS milik operator, muncul Alarm/Problem di BTS, sehingga membutuhkan proses eskalasi oleh FOP dan Vendor Maintenance BTS.

2. Kemudian bagian NOC-Network Coordinator / NOC Monitoring Membuat NFC Access Ticket yang akan di auto Dispatch kepada bagian FOP dan Vendor maintenance BTS (Ericsson, Huawei, NSN, etc) sesuai dengan Region yang di handle oleh masing-masing FOP dan Vendor Maintenance.

3. NFC Access Ticket yang diterima di mobile phone oleh FOP dan Vendor Maintenance hanya digunakan untuk membuka pintu masuk BTS (selama status ticket masih open, FOP dan Vendor Maintenance dapat mengakses keluar masuk pintu BTS).

4. Selama Proses Eskalasi / Troubleshoot dilapangan, FOP dan Vendor Maintenance diwajib melihat Tabel SLA yang sudah dibuat oleh pihak manajemen antara operator telekomunikasi dengan vendor (Tabel SLA vendor berlaku untuk semua vendor dengan operator tertentu).

Tabel 1. SLA Vendor

\begin{tabular}{clc}
\hline No. & Severity & SLA Vendor \\
\hline 1 & Critical & 3 Hours \\
2 & Major & 6 Hours \\
3 & Minor & 24 Hours \\
\hline
\end{tabular}

5. Apabila Status NFC Access Ticket sudah closed, maka FOP dan Vendor Maintenance tidak akan bisa mengakses pintu BTS.

6. Dengan adanya Sistem Monitoring SLA, diharapkan kinerja FOP dan Vendor Maintenance dapat meningkat, selain itu juga dapat membantu pihak manajemen dalam perhitungan SLA Achivement untuk masing-masing vendor.

\section{Usecase Diagram}




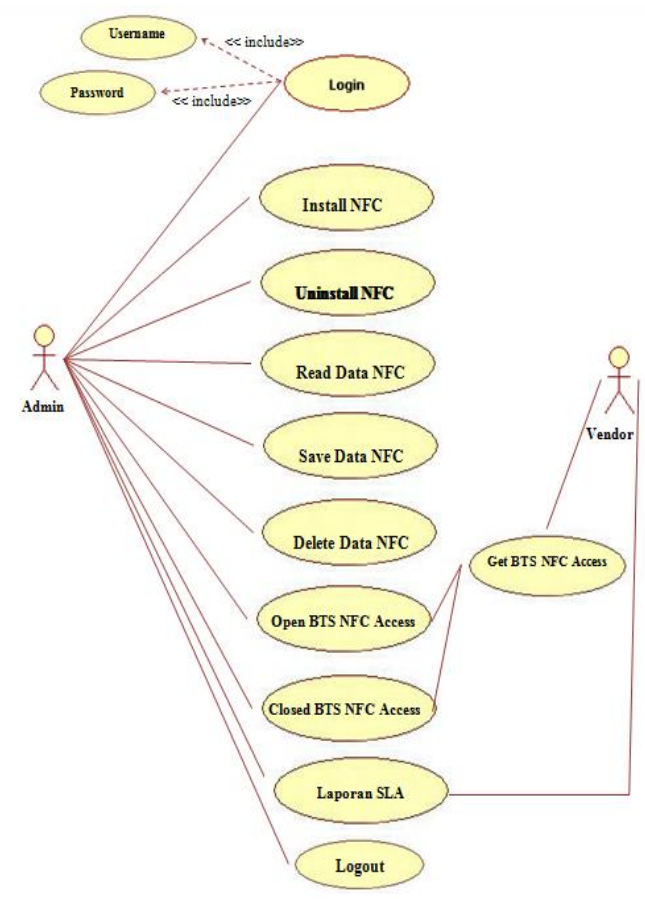

Gambar 6. Usecase Diagram Sistem Personalisasi NFC

Pada gambar 6. usecase diagram diatas menjelaskan secara menyeluruh tentang aktifitas yang dapat dilakukan oleh aktor (dalam hal ini administrator dan vendor) pada sistem personalisasi NFC (Near Field Communication) ini.

\section{Activity Diagram}

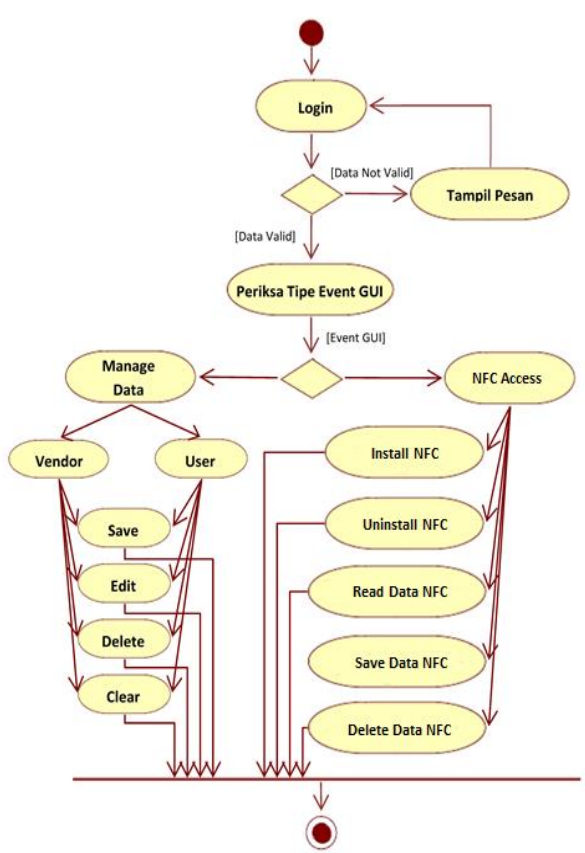

Gambar 7. Activity Diagram Sistem Personalisasi NFC 
Pada gambar 7. Activity diagram diatas menjelaskan secara menyeluruh untuk proses authentication ke sistem personalisasi NFC (Near Field Communication) yang terdiri dari manajemen data vendor dan user (untuk save, edit, delete dan clear data), serta manajemen untuk NFC (Near Field Communication) Tag access yang digunakan untuk melakukan install, uninstall, read, save dan delete data pada NFC (Near Field Communication) tag access.

\section{Sequence Diagram}

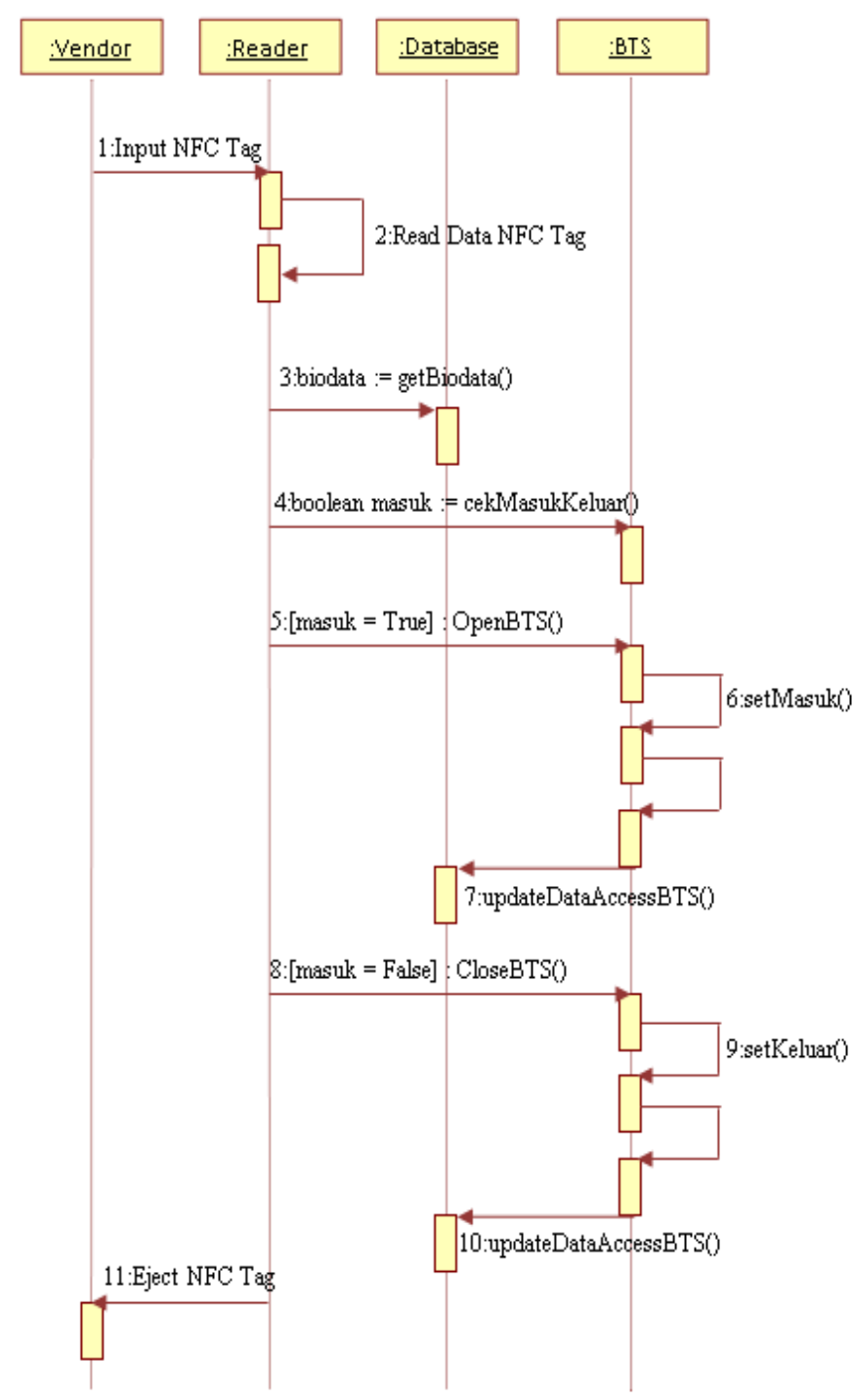

Gambar 8. Sequence Diagram Sistem Personalisasi NFC

Pada gambar 8. Sequence diagram diatas menjelaskan secara menyeluruh untuk proses access NFC Reader pada pintu BTS (Base Tranceiver Station) dengan NFC Tag, sehingga pintu BTS dapat diakses oleh vendor yang akan melakukan troubleshooting pada shelter BTS. 


\section{Tampilan Sistem Personalisasi NFC}

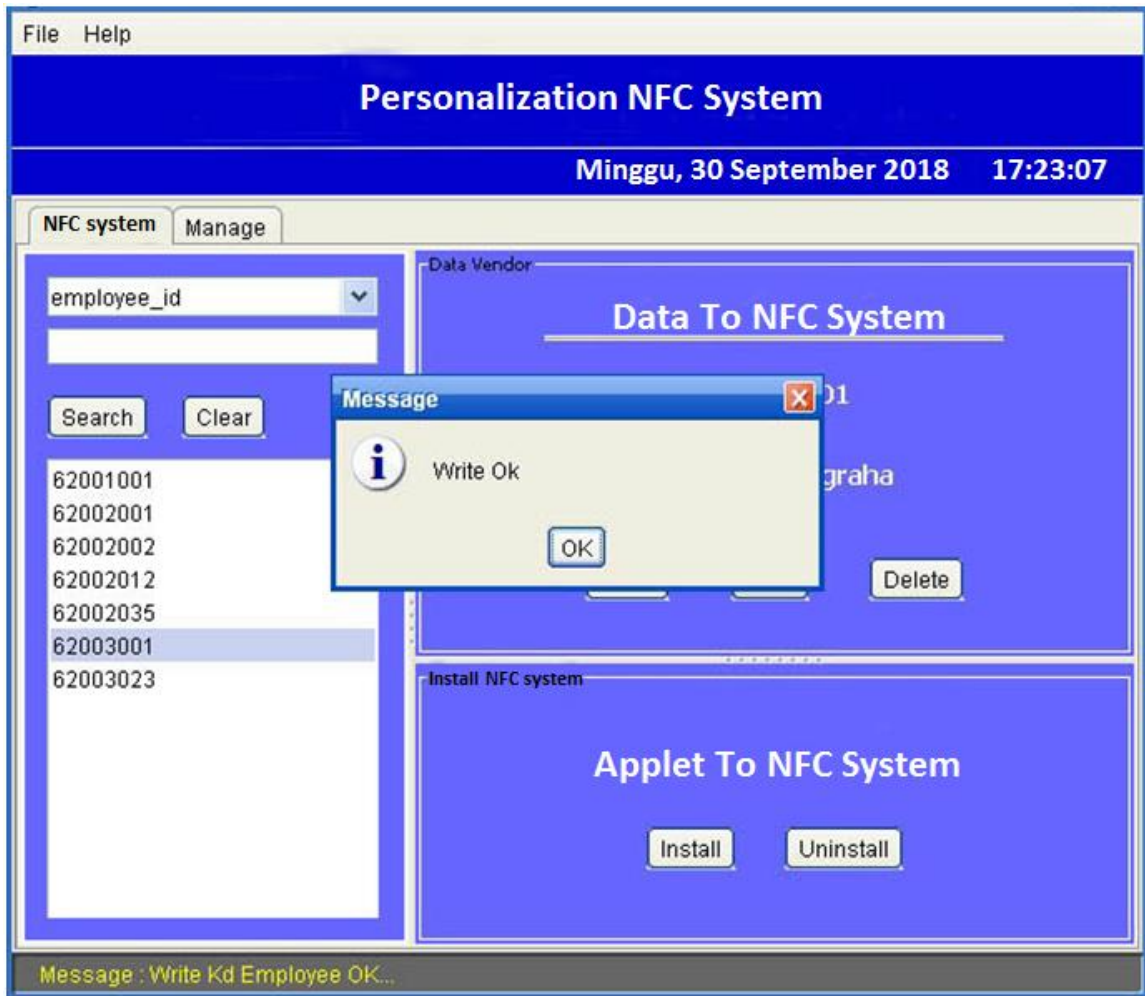

Gambar 9. Tampilan Sistem Personalisasi NFC

Pada gambar 9. Merupakan Tampilan utama dari Sistem Personalisasi NFC untuk halaman administrator dalam melakukan proses manajemen NFC tag (install, uninstall, read, save dan delete data pada NFC) dan manajemen data vendor serta user (untuk save, edit, delete dan clear data), sedangkan untuk tampilan halaman vendor dan user berupa mobile application baik itu android ataupun iOS (iPhone OS).

\section{Hasil analisis metode PIECES}

Tabel 2. Hasil analisis metode PIECES

\begin{tabular}{|c|c|c|}
\hline Aspek & Sistem Berjalan & Sistem Baru \\
\hline$P \epsilon$ & $\begin{array}{l}\text { Sistem akses ke Pintu BTS } \\
\text { dengan sistem yang berjalan itu } \\
\text { menggunakan kunci gembok } \\
\text { manual. selain itu, Sistem } \\
\text { monitoring SLA dilakukan } \\
\text { secara manual oleh pihak } \\
\text { manajemen operator dengan } \\
\text { cara mengumpulkan data dari } \\
\text { masing-masing region secara } \\
\text { manual dan diolah secara }\end{array}$ & $\begin{array}{l}\text { Sistem akses ke pintu BTS } \\
\text { dengan menggunakan teknologi } \\
\text { NFC melalui mobile } \\
\text { smartphone, } \\
\text { memudahkan vendor dalam } \\
\text { melakukan eskalasi } \\
\text { troubleshoot dilapangan. Selain } \\
\text { itu, Sistem Monitoring SLA } \\
\text { dilakukan secara online dan } \\
\text { diolah secara komputasi, }\end{array}$ \\
\hline
\end{tabular}




\begin{tabular}{ll}
\hline & konvesional sehingga \\
memberikan waktu yang lama \\
dan kurang efisien pada proses \\
pengolahan SLA. \\
Pihak Manajemen mengalami \\
kesulitan dalam memonitor \\
Information & SLA setiap vendor dan \\
& kesulitan dalam mengakses \\
& laporan dari kinerja masing- \\
& masing vendor. \\
& Sistem Monitoring SLA yang \\
berjalan banyak merugikan \\
pihak manajemen operator dari \\
segi financial, karena tidak bisa \\
memberikan evidence kepada \\
pihak vendor terkait laporan \\
SLA Achivement masing- \\
masing vendor.
\end{tabular}
masing vendor.

Data-data monitoring SLA vendor kemungkinan dapat dimanipulasi oleh pihak regional masing-masing BTS, sehingga menimbulkan banyak kerugian bagi pihak manajemen operator telekomunikasi.

Sistem yang sedang berjalan dinilai kurang efisien, dikarenakan pada sistem monitoring SLA dan eskalasi trouble ticket masih dilakukan Efficiency secara manual dengan form berupa kertas yang ditulis tangan dan dikumpulkan di masing-masing region, sehingga kurangnya transparansi dalam membuat laporan SLA kinerja setiap sehingga lebih efisien dan cepat.

Pihak Manajemen dapat memonitor SLA vendor serta dapat melihat laporan dari kinerja vendor tersbut secara online dan update.

Sistem Monitoring SLA yang baru akan memakan biaya investasi awal yang besar, akan tetapi setiap Evidence SLA vendor dapat di monitor langsung oleh pihak manajemen operator dan apabila pihak vendor lebih banyak Out of SLA, maka akan dikenakan penalti oleh pihak manajemen operator.

Data-data Monitoring SLA lebih aman, karena data diinput by system oleh vendor yang melakukan troubleshoot, sehingga kemungkinan modifikasi terhadap data sangat kecil.

Dengan adanya sistem monitoring ini, vendor dapat melakukan eskalasi trouble ticket secara lansung menggunakan smartphone pribadinya. Sistem ini dinilai lebih efisien jika di bandingkan dengan sistem yang sedang berjalan. Pada sistem ini juga vendor dapat melihat laporan dari kinerja mereka secara 
vendornya.

Pelayanan yang diberikan pada sistem monitoring SLA yang diberikan kurang baik dikarenakan pihak manajemen

Services kesulitan dalam memonitor SLA vendor, selain itu juga Vendor tidak bisa melihat laporan dari kinerja mereka. transparan dan update.

Dengan adanya sistem monitoring online menggunakan JSP dan mobile android ini dapat memberikan kemudahan kepada pihak manajemen untuk memonitor kinerja vendor. Selain itu juga akan membantu pihak vendor untuk pengaksesan pintu BTS.

\section{Uji Coba Akurasi Pembacaan Sistem Personalisasi NFC dengan NFC Reader}

Pada penelitian ini dikembangkan suatu prototype untuk sistem personalisasi dan monitoring SLA, sehingga dapat diketahui persentase tingkat akurasi pembacaan process NFC access untuk setiap prosesnya yang terdiri dari, Proses Install NFC, Uninstall NFC, Read Data $N F C$, Save Data NFC dan Delete Data NFC. Untuk menghitung persentase akurasi Pembacaan Sistem Personalisasi NFC dengan NFC Reader, dilakukan uji coba sampling pembacaan process NFC access masing-masing sebanyak 100 kali sampling pembacaan data untuk setiap prosesnya, maka dari hasil uji coba didapat hasil rata-rata persentase tingkat akurasi pembacaan process NFC access sebagai berikut:

Tabel 3. Uji Coba Akurasi Pembacaan Sistem Personalisasi NFC dengan NFC Reader

\begin{tabular}{|c|c|c|c|c|}
\hline \multirow{2}{*}{ Process NFC Access } & \multicolumn{2}{|c|}{$\begin{array}{c}\text { Uji Coba sebanyak } 100 \\
\text { kali Percobaan }\end{array}$} & \multicolumn{2}{|c|}{ Total Persentase } \\
\hline & $\begin{array}{l}\text { Total } \\
\text { Sukses }\end{array}$ & $\begin{array}{l}\text { Total } \\
\text { Gagal }\end{array}$ & $\begin{array}{l}\text { PersentaseTotal } \\
\text { Sukses }\end{array}$ & $\begin{array}{c}\text { PersentaseTotal } \\
\text { Gagal }\end{array}$ \\
\hline Proses Install NFC & 99 & 1 & $99 \%$ & $1 \%$ \\
\hline Proses Uninstall NFC & 99 & 1 & $99 \%$ & $1 \%$ \\
\hline Proses Read Data NFC & 100 & 0 & $100 \%$ & $0 \%$ \\
\hline Proses Save Data NFC & 99 & 1 & $99 \%$ & $1 \%$ \\
\hline $\begin{array}{l}\text { Proses Delete Data } \\
\text { NFC }\end{array}$ & 99 & 1 & $99 \%$ & $1 \%$ \\
\hline $\begin{array}{l}\text { Rata-Rata Pembacaan } \\
\text { Process NFC Access }\end{array}$ & 99,2 & 0,8 & $99,20 \%$ & $0,8 \%$ \\
\hline
\end{tabular}

\section{PENUTUP}

Simpulan

Berdasarkan hasil dari penelitian yang telah dilakukan, Beberapa kesimpulan yang dapat ditarik antara lain:

1. Berdasarkan hasil uji coba pembacaan sistem personalisasi NFC dengan NFC Reader yang dilakukan sebanyak 100 kali uji coba, maka diperoleh rata-rata pembacaan process NFC Access sebesar 99,2\% untuk persentasi total sukses dan 0,8\% untuk persentase total gagal. Dari perbandingan persentase rata-rata pembacaan process NFC Access, bisa dikatakan hasilnya sangat akurat, dan patut dijadikan bahan pertimbangan untuk operator telekomunikasi dalam mengimplementasikan sistem ini. 
2. Dengan adanya rancangan sistem ini, dapat membantu operator telekomunikasi dalam memonitor SLA vendor, sehingga performa vendor dapat termonitor. Selain itu juga, membantu pihak yang berkepentingan (dalam hal ini, pihak manajemen operator telekomunikasi) dalam penilaian kinerja suatu vendor yang disertai dengan data evidence yang diperoleh dari sistem personalisasi NFC ini.

\section{Saran}

Berdasarkan hasil dari penelitian yang telah dilakukan, berikut ini beberapa saran untuk pengembangan sistem ini, antara lain:

1. Menggunakan validator pada sistem untuk mengeliminasi kemungkinan fraud. Contoh validator adalah sensor tambahan berupa fingerprint sensor atau face recognizer yang di tempatkan di masing-masing pintu akses BTS (Base Tranceiver Station). Sehingga meski ada pengguna curang yang menggandakan tag NFC, maka ia harus melewati tahapan validasi menggunakan sensor-sensor tersebut.

2. Untuk implementasi sistem ini akan banyak membutuhkan biaya yang tidak sedikit dikarenakan harga hardware NFC Reader untuk akses pintu disetiap BTS (Base Tranceiver Station) terbilang tinggi.

\section{DAFTAR PUSTAKA}

A. Dayumi and M. Femy. 2018. Sistem Absensi Karyawan Berbasis Location Based Services (LBS) Menggunakan Platform Android Studi Kasus: PT.Noxus Ideata Prima. Jurnal Sistem Komputer \& Kecerdasan Buatan. Vol. 2 No.1. Jakarta: Universitas Tanri Abeng.

Dynastya., \& Haryo S. 2013. Model Lokasi Menara BTS ditinjau dari Faktor-faktor penentu lokasi Menara BTS di Surabaya. jurnal Institute Sepuluh November.

Lee, H. 2014. A User-Friendly Authentication Solution using NFC Card Emulation on Android. Rismawati, Nofita. 2016. Sistem Absensi Dosen Menggunakan Near Field Communication (NFC) Technology. Jurnal Faktor Exacta. Vol. 9 No.2. Jakarta: Universitas Indraprasta PGRI.

Statista. 2011. Number of smartphone users in Indonesia from 2011 to 2017. URL=http://www.statista.com/statistics/266729/smartphon e-users-in-indonesia.

http://cetek.web.id/content/cara-kerja-teknologi-nfc-\%E2\%80\%9Cnear-

fieldcommunication\%E2\%80\%9D, di akses pada 25 September 2018.

https://nicoruslim.wordpress.com/2014/07/20/rfid-nfc-mode-aktif-dan-pasif/, di akses pada 29

September 2018. 